\title{
Longitudinal SARS-CoV-2 Seroconversion Course and Antibody Levels by Blood Groups in Convalescent Plasma Donors in Turkey
}

\author{
Türkiye'deki İmmün Plazma Bağış̧ılarında SARS-CoV-2 \\ Serokonversiyonunun Uzun Süreli Seyri ve Kan Gruplarına Göre \\ Antikor Seviyeleri
}

\author{
Aziz KARACA $\odot$, Mustafa Nuri GUNCIKAN $\odot$, Nazlı Nadire SOZMEN $\odot$, Gizem Gokce KARADAG $\odot$, \\ Mustafa YILMAZ $\odot$, Kerem KINIK ๑, Fatma Meric YILMAZ ๑
}

Ethics Committee Approval: This study was approved by Turkish Red Crescent General Directorate of Blood Services, Non-invasive research ethics committee, 12 February 2021, 2021/04.

Conflict of interest: The authors declare that they have no conflict of interest.

Funding: None.

Informed Consent: Not Applicable.
Cite as: Karaca A, Guncikan MN, Sozmen NN, et al. Longitudinal SARS-CoV-2 seroconversion course and antibody levels by blood groups in convalescent plasma donors in Turkey. Medeni Med J. 2021;36:185-92.

\begin{abstract}
Objective: The present study investigates the seroconversion time course of the IgG antibody against SARS-CoV-2 and ascertains whether its levels change according to the patient's $A B O$ blood group.

Method: A total of 36,003-convalescent plasma (CP) donations of 12,315 Turkish Red Crescent $C P$ donors were analyzed. The $A B O$ blood group of the $C P$ donors was determined by $\mathrm{Gel}$ Centrifugation; and IgG was measured using the Euroimmun anti-SARS-CoV-2 ELISA. The differences in the distributions of mean IgG ratios among the different ABO blood groups were analyzed with One-Way ANOVA and Independent Samples T-test.

Results: Among the CP donors, $98.4 \%$ were male. An antibody response to SARS-CoV-2 was noted-although in a few CP donors- on the 244th day, and a significant association between the $A B O$ blood groups and the mean IgG ratios was noted ( $p: 0.001)$. The highest (mean $\pm S D$ antibody level was observed in the $A B$ blood group (39.5 15.7$)$, followed by the $B(37.9 \pm 11.5)$ and the $A$ blood groups (36.6 \pm 10.7$)$, while the lowest value was recorded in the $O$ blood group (34.4 11.5). Significant differences between all paired groups were noted in pairwise comparisons. The Rh (-) blood group (37.4 13.6) had a significantly higher antibody level than the $R h(+)$ blood group (36.3 \pm 11.2$)$ (p: 0.005).

Conclusion: An antibody response to SARS-CoV-2 was noted in a CP donor on the 244th day. The average IgG ratios were higher in the $C P$ donors with the $A B$ blood group, but lower in the $O$ blood group. These results may be considered a valuable indication of the effectiveness of $C P$ therapy used for the treatment of COVID-19 patients with clinically relevant blood types.
\end{abstract}

Keywords: ABO blood group, COVID-19, SARS CoV-2, Seroconversion, Convalescent plasma

öz

Amaç: SARS-CoV-2'ye karşı IgG antikorunun zamansal seyrini ve ABO kan grubuna göre düzeyinin değișip değişmediğini belirlemeye çalıştık.

Yöntem: Türk Kızılay'ın 12315 konvalesan plazma (KP) bağışçısının 36003 KP bağışını inceledik. $K P$ bağısçılarının $A B O$ kan grubu, Gel Centrifugation yoluyla belirlendi. IgG, Euroimmun antiSARS-CoV-2 ELISA kullanılarak ölçüldü. Ortalama IgG oran dağılımındaki farklııklar, One Way ANOVA ve Independent Sample T testleri kullanılarak $A B O$ kan grubuna göre incelendi. Bulgular: KP bağışçılarının \%98,4'ü erkeklerden oluşmaktadır. KP bağışçılarında SARS-CoV-2'ye antikor yanıtının -birkaç kissiyle sınırlı olmakla birlikte- yaklassı 244. günde görüldüğünü saptadık. $A B O$ kan grupları ile ortalama IgG oranları arasında anlamlı bir ilişsi saptadık (p:0.001). En yüksek antikor seviyesi (mean $\pm S D$ ) AB kan grubunda gözlenirken $(39,5 \pm 15,7)$, onu $B$ kan grubu (37.9 $\pm 11,5)$, sonra $A$ kan grubu $(36,6 \pm 10,7)$ izlerken, en düsük $O$ kan grubunda $(34,4 \pm 11,5)$ idi. Yine ikili grup karşılaştırmasında da tüm ikili gruplar arasında anlamlı farklılıklar vardı. Rh (-) kan grubunda $(37,4 \pm 13,6)$; $R h(+)$ kan grubuna $(36,3 \pm 11,2)$ göre anlamlı düzeyde daha yüksek antikor seviyesi mevcuttu (p:0,005).

Sonuç: SARS-CoV-2'ye antikor yanıtının yaklassık 244. günde görüldügünü saptadık. Kan grubu $A B$ olan KP bağışçılarında ortalama IgG oranları daha yüksek iken; O grubunda daha düşüktü. Klinik olarak ilgili kan grubuna sahip COVID-19 hastalarının tedavisinde kullanılacak olan KP tedavisinin etkinliğinde bu sonuçlar değerli olabilir.

Anahtar kelimeler: ABO kan grubu, COVID-19, SARS-CoV-2, serokonversiyon, immün plazma
Received: 04 June 2021 Accepted: 30 August 2021 Online First: 30 September 2021

Corresponding Author: A. Karaca ORCID: 0000-0001-9408-5073

Turkish Red Crescent, General

Directorate of Blood Services, Directorate of Medical Management, Ankara, Turkey

drazizkaraca@gmail.com

M.N. Guncikan

ORCID: 0000-0003-3274-7574

N.N. Sözmen

ORCID: 0000-0002-7783-0366

G.G. Karadag

ORCID: 0000-0003-0989-5982

M. Yilmaz

ORCID: 0000-0003-3266-4752

Turkish Red Crescent, General

Directorate of Blood Services, Directorate of Medical Management, Ankara, Turkey

K. Kinik

ORCID: 0000-0002-6913-5312 Turkish Red Crescent, Managing Board, Ankara, Turkey

F.M. Yilmaz ORCID: 0000-0001-6112-3950 Yıldırım Beyazıt University, Faculty of Medicine, Ankara, Turkey 


\section{INTRODUCTION}

In the last days of 2019, the COVID-19 disease caused by the etiological agent SARS-CoV-2 emerged in the city of Wuhan in the Hubei province of the People's Republic of China. The ongoing pandemic has been seen in over 209 million people infected to date, with deaths amounting to over 4.3 million people in 224 countries/regions around the world ${ }^{1}$. In Turkey, the number of cases has surpassed 5.7 million and around 51,000 deaths have been recorded ${ }^{2}$. The antibody response in patients infected with SARS-CoV-1 during an earlier coronavirus outbreak has been reported to be detected even 36 months after infection in $89 \%$ of those infected ${ }^{3}$. Similarly, antibody response in patients following MERS-CoV infection was reported to be detected 34 months after the infection ${ }^{4}$. In most of those infected with SARS-CoV-2, the antibody response starts to be effective approximately 10-14 days after infection ${ }^{5}$. There have been many studies to date assessing the long-term course of this antibody response ${ }^{6}$, although it is yet unclear how long this response will continue for SARSCoV-2 infections.

There is still no definitive cure for the disease, although the U.S. Food and Drug Administration $(\mathrm{FDA})^{7}$ and the European Comission ${ }^{8}$ have both approved the use of Convalescent Plasma (CP) taken from recovered COVID-19 patients for the treatment of current patients. Accordingly, having been granted approval by the Turkish Ministry of Health', the Turkish Red Crescent (TRC) has started to accept $\mathrm{CP}$ donations. It has been recently discovered that the risk level of the disease depends on the $A B O$ group of the individual (the risk of COVID-19 is greater in A group than those in the $O$ group $)^{10,11}$. Little is known about the link between SARS-CoV-2 IgG level and the $A B O$ blood groups in humans, and as such antibody levels and their longitudinal course during the disease related to specific blood groups remain unclear. If a significant difference in SARS-CoV-2 IgG levels in different ABO blood groups can be identified, it may have important clinical implications for the prediction of the possible efficacy of CP in the COVID-19 treatment of people with certain blood groups.

The present study assesses the antibody levels and the longitudinal course of antibody response following SARS-CoV-2 infection in CP donors, as well as the antibody levels in the $A B O \&$ Rh blood groups, and the effect of Body Mass Index (BMI), and age on antibody levels.

\section{MATERIAL and METHODS}

\section{Study Design}

This study was approved by the Ethical Board of the TRC Blood Services General Directorate (2021/4; 12.02.2021). The digital archives of the TRC were analyzed as part of a retrospective cohort study covering the period between April 7, 2020 and December 11, 2020, revealing that 12,315 persons donated CP at TRC Blood Donation Centers with a total of $36,003 \mathrm{CP}$ donations in the given period. All donors provided written consent prior to plasma donations. The eligibility criteria for inclusion in the study were, in line with the requirements of COVID-19 Immune (Convalescent) Plasma Supply and Clinical Usage Guide?:

(1) A positive laboratory test (nasopharynx swab PCR test or SARS-CoV-2 antibodies serological test) and,

(2) Two negative PCR test results from nasopharyngeal swab (one of which from within the previous 48 hours) 14 days after the resolution of clinical symptoms (cough, fever, dyspnea, fatigue, etc.) or;

(3) If 28 days have passed since the resolution of clinical symptoms, a negative PCR test is not necessary.

For the semi-quantitative in vitro determination of human antibodies of the immunoglobulin class IgG against SARS-CoV-2 in serum, an Anti-SARS- 
CoV-2 ELISA (IgG) (Euroimmun, Germany Order no: EI 2606-9601 G) was used. The test kits contained microplate strips with reagent wells coated with an S1 domain of the spike protein of SARS-CoV-2, expressed recombinantly in the human cell line HEK 293.

The sample dilution and test performance were carried out using a Euroimmun Analyzer I device (Euroimmun AG, Germany). In the first reaction step, diluted (1:101 in sample buffer) donor plasma samples were incubated in the wells, and in case of positive test results, specific IgG antibodies were bound to the antigens. To detect the bound antibodies, a second incubation was carried out using enzyme-labelled anti-human IgG (enzyme conjugate) to catalyze a color reaction. The results were evaluated semi-quantitatively by calculating the ratio of the extinction of the control or donor sample to the extinction of the calibrator, using Euroimmun Analyzer I software (Ratio <0.8: Negative Ratio; $\geq 0.8$ to $<1.1$ : Borderline Ratio; $\geq 1.1$ : Positive).

Samples with a SARS-CoV-2 IgG ratio below 1.1 were excluded from the study. To ensure those with values above this continued to donate after making their first donation, the SARS-CoV-2 IgG ratio checked before each donation had to be above 1.1. For the ongoing donations of these donors, however, the last donations, even if the SARS-CoV-2 IgG ratio was below 1.1 , were included in the study to observe the longitudinal course of antibody levels. Blood groupings were carried out with the Gel Centrifugation method using a Grifols (Grifols-Erytra, Spain) device and Grifols (Grifols, Spain) kits.

\section{Statistical Analysis}

Descriptive statistics of all parameters were evaluated. While assessing whether the variables showed a normal distribution, a Shapiro Wilk test and/or a Kolmogorov-Smirnov test were used, depending on the frequencies. In the statistical assessment, the level of significance was accepted as 0.05 .

In a statistical assessment of the differences between groups, a Mann-Whitney $U$ and/or an Independent Samples T test; along with a Kruskal Wallis $\mathrm{H}$ and a One-Way ANOVA, were used depending on whether the variables were normally distributed. When comparing more than two groups, if significant differences were found, and after checking the homogeneity of variances, the significant differences between groups were assessed using Tukey HSD/Tamhane's T2 and/or Mann-Whitney U tests with Bonferroni correction. The results were regarded significant if $p<0.05$. IBM SPSS was used for the statistical analyses (Version 25.0. Armonk, NY: IBM Corp.).

\section{RESULTS}

The mean age of CP donors was 36.6 (min-max: 18-60) years. The gender distribution of the CP donors was $98.4 \% / 1.6 \%$ (males/females). The high male to female ratio among $\mathrm{CP}$ donors was seen because the TRC does not accept plasma donations of any kind from women with a pregnancy history, including miscarriages or D/C, due to the risk of transfusion-related acute lung injury (TRALI) in the recipient. The average BMI of the CP donors was $27.4 \mathrm{~kg} / \mathrm{m}^{2}$ (min-max, 15.5$48.9 \mathrm{~kg} / \mathrm{m}^{2}$ ).

The number of $\mathrm{CP}$ donors by weeks since the onset of PCR positivity are shown in Figure 1. The SARSCoV-2 IgG ratios and seroconversion times are shown in Figure 2. In this study, we observed the presence of an ELISA SARS-CoV-2 IgG antibody ratio up to the $244^{\text {th }}$ day following the onset of PCR positivity (data not shown in Figure 2 ).

The IgG antibody levels in the different blood groups are shown in Tables 1 and 2 . There is a significant difference in the mean IgG antibody ratios of the different $A B O$ groups (p:0.001). The highest mean IgG antibody ratio was observed in 


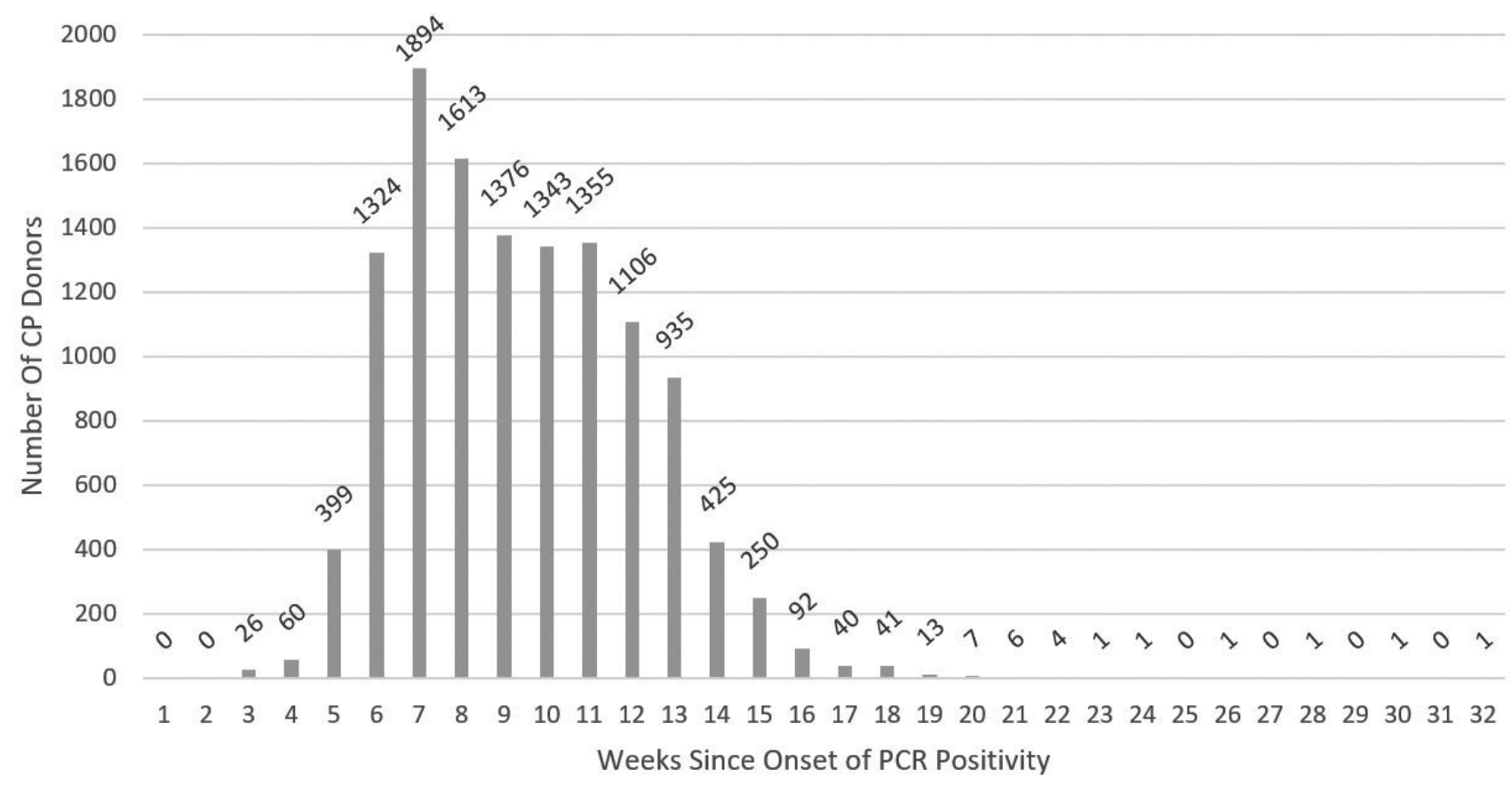

Figure 1. Number of CP donors by weeks since the onset of PCR positivity.

\section{SARS-CoV-2 IgG Response}

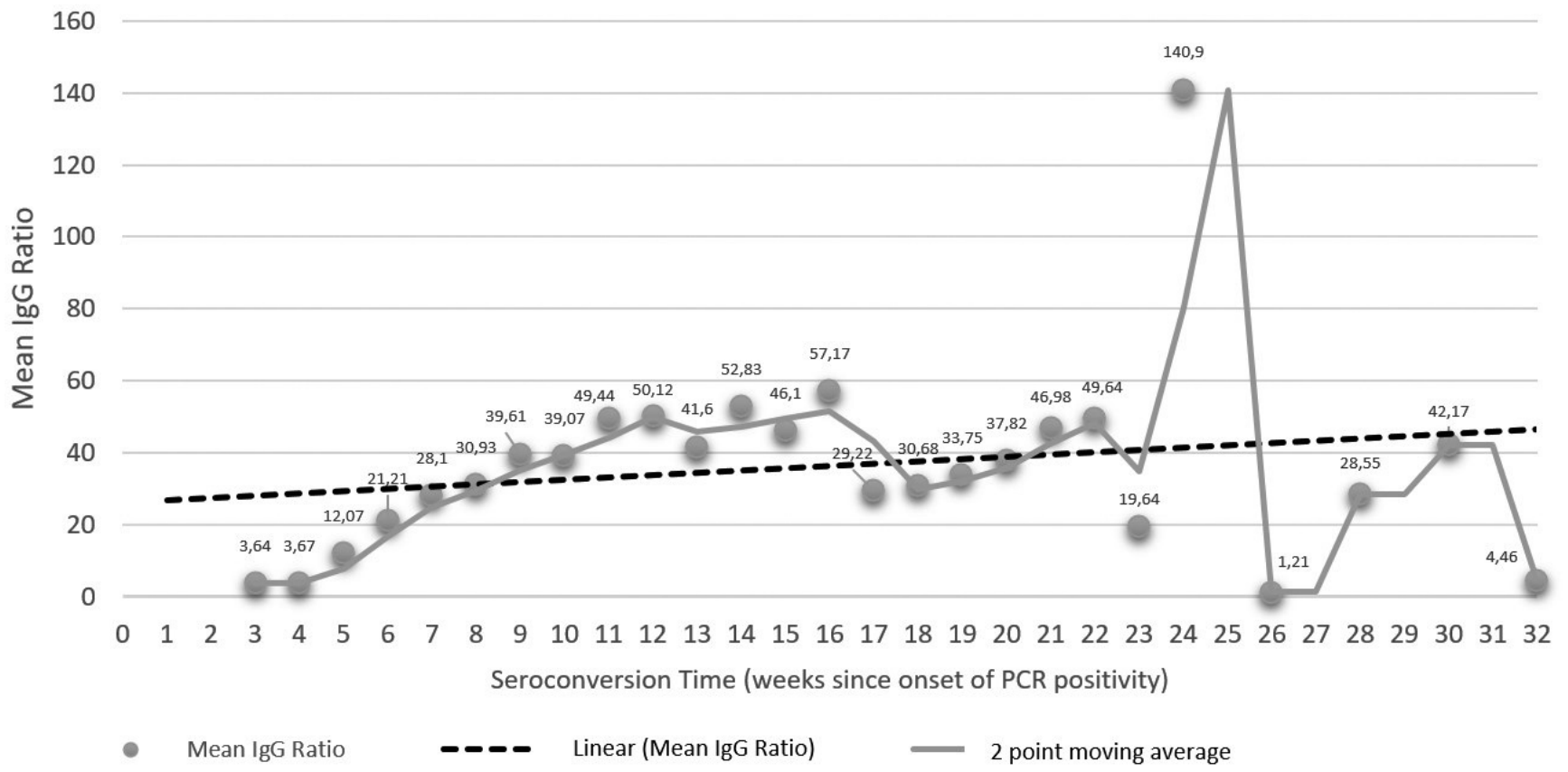

Figure 2. SARS-CoV-2 IgG ratio and seroconversion time.

the AB blood group (39.5) while the lowest was recorded in the O blood group (34.4). Significant differences were observed in all pairwise group comparisons. Likewise, in the Rh (-) blood group a higher mean IgG antibody ratio was noted than the Rh (+) blood group (p:0.005) (Table 1). 
A. Karaca et al. Longitudinal SARS-CoV-2 Seroconversion Course and Antibody Levels by Blood Groups in Convalescent Plasma Donors in Turkey

There is a significant difference in the mean IgG antibody ratios among the $\mathrm{ABO} \& \mathrm{Rh}$ group combinations ( $p: 0.001$ ). The highest mean IgG antibody ratio was observed in the $A B$ Rh (+) blood group (40.06), while the lowest was recorded in the $\mathrm{O}$ Rh (+) blood group (33.76). Significant differences were observed in the pairwise group comparisons (Table 2). Those in which no significant difference observed were excluded for clarity.

The CP donors in the present study were divided into groups of young (18-34 years old) and older adults (35-60 years old), in accordance with the study by Ward et al. ${ }^{12}$, and a significant difference

Table 1. Mean IgG antibody ratios in ABO and $\mathrm{Rh}$ blood groups.

\begin{tabular}{|c|c|c|c|c|c|c|}
\hline \multirow[b]{2}{*}{ Group } & \multicolumn{4}{|c|}{ IgG Ratio } & \multirow[b]{2}{*}{$\begin{array}{l}\text { Significant } \\
\text { differences } \\
\text { between } \\
\text { groups }\end{array}$} & \multirow[b]{2}{*}{$\mathbf{p}^{\mathbf{c}}$} \\
\hline & $\overline{\text { n (\%) }}$ & Mean & SD & $\mathbf{p}$ & & \\
\hline A & $5758(47.0)$ & 36.6 & 10.7 & & A-B & 0.001 \\
\hline B & $1990(16.2)$ & 37.9 & 11.5 & $0.001^{a}$ & $A-A B$ & 0.001 \\
\hline$A B$ & $1044(8.5)$ & 39.5 & 15.7 & & $\mathrm{O}-\mathrm{A}$ & 0.001 \\
\hline $\mathrm{O}$ & $3470(28.3)$ & 34.4 & 11.5 & & $B-A B$ & 0.023 \\
\hline $\mathrm{Rh}(+)$ & $10940(89.2)$ & 36.3 & 11.2 & $0.005^{\mathrm{b}}$ & O-B & 0.001 \\
\hline $\mathrm{Rh}(-)$ & $1322(10.8)$ & 37.4 & 13.6 & 0.005 & $O-A B$ & 0.001 \\
\hline
\end{tabular}

"One-Way ANOVA Test

${ }^{b}$ Independent Samples T Test

'The groups with significant intergroup differences were determined by Tamhane's T2 Test.

SD: Standard Deviation was noted between the mean IgG ratios of the age groups (p:0.001) (Table 3). A significant difference was also noted between the mean IgG antibody ratios of the BMI groups (p:0.001), with an increase in the mean IgG antibody ratios noted

Table 2. Mean IgG antibody ratios in ABO\&Rh blood group combinations.

\begin{tabular}{|c|c|c|c|c|c|c|}
\hline \multirow[b]{2}{*}{ Group } & \multicolumn{4}{|c|}{ IgG Ratio } & \multirow[b]{2}{*}{$\begin{array}{l}\text { Significant } \\
\text { differences } \\
\text { between } \\
\text { groups }\end{array}$} & \multirow[b]{2}{*}{$\mathbf{p}^{\mathbf{b}}$} \\
\hline & n (\%) & Mean & SD & $\mathbf{p}^{a}$ & & \\
\hline $\mathrm{A}(+)$ & $5119(41.7)$ & 36.1 & 10.5 & & $\mathrm{~A}(+)$ vs $\mathrm{A}(-)$ & 0.01 \\
\hline$A(-)$ & $639(5.2)$ & 38.3 & 14.6 & & $\mathrm{~A}(+)$ vs B (+) & 0.001 \\
\hline $\mathrm{B}(+)$ & $1772(14.5)$ & 38.1 & 11.0 & & $\mathrm{~A}(+)$ vs $\mathrm{AB}(+)$ & 0.001 \\
\hline B $(-)$ & $218(1.8)$ & 36.9 & 16.9 & & $\mathrm{~B}(+)$ vs $\mathrm{AB}(+)$ & 0.016 \\
\hline $\mathrm{AB}(+)$ & 928 (7.6) & 40.1 & 15.6 & 0.001 & $\begin{array}{l}0(+) \text { vs } A(+) \\
0(+) \text { vs A (-) }\end{array}$ & $\begin{array}{l}0.001 \\
0.001\end{array}$ \\
\hline$A B(-)$ & $116(0.9)$ & 35.2 & 20.9 & & $\begin{array}{l}0(+) \text { vs } B(+) \\
0(+) \text { vs } A B(+)\end{array}$ & $\begin{array}{l}0.001 \\
0.001\end{array}$ \\
\hline $0(-)$ & $349(25.5)$ & 37.0 & 11.9 & & $0(+)$ vs $0(-)$ & 0.001 \\
\hline $0(+)$ & $3121(2.8)$ & 33.8 & 13.1 & & $0(-)$ vs $A B(+)$ & 0.012 \\
\hline
\end{tabular}

ane-Way ANOVA Test

${ }^{b}$ The groups with significant intergroup differences were determined by Tamhane's T2 Test.

$S D$ : Standard Deviation

Table 3. Mean IgG antibody ratios by age.

\begin{tabular}{|c|c|c|c|c|}
\hline \multirow[b]{2}{*}{ Age (years) } & \multirow[b]{2}{*}{ n (\%) } & \multicolumn{2}{|c|}{ IgG Ratio } & \multirow{2}{*}{$\begin{array}{l}\text { Analysis } \\
\mathbf{p}^{\mathbf{a}}\end{array}$} \\
\hline & & Mean & SD & \\
\hline $\begin{array}{l}18-34 \\
35-60\end{array}$ & $\begin{array}{l}4972(40.4) \\
7328(59.6)\end{array}$ & $\begin{array}{l}31.4 \\
39.7\end{array}$ & $\begin{array}{l}42.3 \\
47.4\end{array}$ & 0.001 \\
\hline
\end{tabular}

a'Mann-Whitney U Test

$S D$ : Standard Deviation

Table 4. Mean IgG antibody ratios by BMI groups.

\begin{tabular}{|c|c|c|c|c|c|}
\hline \multirow[b]{2}{*}{ BMI kg/m² } & \multicolumn{3}{|c|}{ IgG Ratio } & \multirow[b]{2}{*}{$\begin{array}{l}\text { Significant differences } \\
\text { between groups }\end{array}$} & \multirow[b]{2}{*}{$\mathbf{p}^{\mathbf{b}}$} \\
\hline & n (\%) & Mean & SD $\mathbf{p}^{a}$ & & \\
\hline$<18.5$ & $58(0.5)$ & 25.2 & 41.3 & $<18.5$ vs $18.6-24.9$ & 0.999 \\
\hline $18.6-24.9$ & $3090(25.7)$ & 28.1 & 39.5 & $<18.5$ vs $25-29.9$ & 0.070 \\
\hline $25-29.9$ & $6024(50.1)$ & 37.8 & ${ }^{46.2} 0.001$ & $\begin{array}{l}<18.5 \text { vs } \geq 30 \\
18.6-24.9 \text { vs } 25-29.9\end{array}$ & $\begin{array}{l}0.002 \\
0.001\end{array}$ \\
\hline$\geq 30$ & $2854(23.7)$ & 43.5 & 49.4 & $\begin{array}{l}18.6-24.9 \text { vs } \geq 30 \\
25-29.9 \text { vs } \geq 30\end{array}$ & $\begin{array}{l}0.001 \\
0.001\end{array}$ \\
\hline
\end{tabular}

aOne-Way ANOVA Test

${ }^{b}$ The groups with significant intergroup differences were determined by Tamhane's T2 Test.

SD: Standard Deviation 
as the BMI increases. Some significant differences were observed in pairwise group comparisons (p:0.001) (Table 4).

\section{DISCUSSION}

The eight-month temporal dynamics of the SARSCoV-2 antibody response in CP donors was analyzed in the present study, and the presence of a SARS-CoV-2 antibody was observed up to the $244^{\text {th }}$ day following the onset of PCR positivity. A review of previous studies revealed that earlier studies were limited to shorter follow-up periods (30-90 days) $)^{13-18}$, while later studies with mediumand long-term follow up periods reported the lingering presence of antibodies for longer periods $(91-180 \text { days })^{19-23}$ and (>180 days $)^{24-28}$.

In the present study, CP donations were more frequently made within the 5 to 15 weeks following the onset of PCR positivity. The mean IgG antibody ratios started to increase on the $29^{\text {th }}$ day up to the $112^{\text {th }}$ day, after which they followed a decreasing trend, although their presence was still observed up to the $244^{\text {th }}$ day. In the study by Karbiener et al. ${ }^{29}$ most of the CP donations were made between days 20-95 following COVID-19, and the mean IgG antibody ratios were noted to increase on the $20^{\text {th }}$ day up to the $36^{\text {th }}$ day, decreasing slowly until the $95^{\text {th }}$ day. Likewise, the persistence of antibody response was reported up to the $168^{\text {th }}$ ( Maine et al. ${ }^{30}$ ), $195^{\text {th }}$ (Gaebler et al. ${ }^{25}$ ), $210^{\text {th }}$ (Mai et al. ${ }^{26}$ ), and $240^{\text {th }}$ days ( Dan et al. ${ }^{27}$ ) by indicated authors.

In the present study, a significant association was found between the $A B O$ blood groups and the mean IgG antibody ratios (p:0.001). The highest mean IgG antibody ratio was observed in the $A B$ blood group, followed by blood groups of $B, A$ and $\mathrm{O}$, respectively. In pairwise group comparisons, a significant difference was noted between all the pairs. In addition, the Rh (-) group had a significant higher mean IgG antibody ratio than the Rh (+) group. Unlike our study, Bloch et al. ${ }^{31}$ identified no significant association between the ABO blood groups and the mean IgG antibody ratios, but reported a significant difference in the SARS-CoV-2 nAb titer (mean log2 (AUC) \pm SD) between the $A B O$ blood groups, with the $B$ blood group recording a significantly higher $\mathrm{nAb}$ titer $(6.4 \pm 2.4)$ than the $O$ blood group $(5.3 \pm 2.2)$, and again, the $A$ blood group (5.5 \pm 2.4$)$ and $A B$ blood group $(4.4 \pm 2.1)$ had significantly lower $n A b$ titers than the B blood group. In contrast, Wendel et al. ${ }^{23}$ found no significant difference in the SARSCoV-2 nAb titers of the ABO blood groups.

In the present study, significant differences were noted between the $\mathrm{ABO}$ and $\mathrm{Rh}$ blood group combinations, with the highest mean IgG antibody ratio observed in the $A B \mathrm{Rh}(+)$ blood group, then in decreasing order of frequency in the $A \mathrm{Rh}(-)$, B Rh (+), 0 Rh (-), B Rh (-), A Rh (+), AB Rh (-) and $0 \mathrm{Rh}(+)$ groups. Our literature review revealed no previous study investigating the association between the mean IgG antibody ratio and the $\mathrm{ABO}$ and Rh blood group combinations.

In our study, the $\mathrm{CP}$ donors were categorized as young (18-34 years old) and older adults (35-60 years old), in accordance with the study of Ward et al. ${ }^{12}$, and the mean IgG antibody ratio was significantly higher in the 35-60 years old group when compared to the 18-34 years old group. While earlier studies have identified different mean IgG antibody ratios in different age groups, no clear or significant association was established between higher antibody levels and increasing age $^{32-34}$. In the present study, a significant association was noted between the mean IgG antibody ratios and BMIs according to the WHO categorization $^{35}$ and the highest mean IgG antibody ratio was identified in those with BMI $\geq 30 \mathrm{~kg} / \mathrm{m}^{2}$, followed by those with BMI 25-29.9 $\mathrm{kg} / \mathrm{m}^{2}$, BMI $18.6-24.9 \mathrm{~kg} / \mathrm{m}^{2}$ and BMI $<18.5 \mathrm{~kg} /$ $\mathrm{m}^{2}$. In some studies, it was emphasized that a significant positive association existed between body weight and SARS-CoV-2 antibody titers $^{23,29,36}$. 
A. Karaca et al. Longitudinal SARS-CoV-2 Seroconversion Course and Antibody Levels by Blood Groups in Convalescent Plasma Donors in Turkey

\section{Limitations}

The $98.4 \%$ of our CP donors, were male and so our results are not generalizable to both genders. As a further limitation of the study, the mean IgG antibody ratios were not measured at fixed intervals. Furthermore, at a certain point in time following PCR positivity, the number of CP donors per week started to decrease. There is also a lack of information on disease severity and the comorbidities of the donor.

One advantage of having the TRC as the major responsible institution for the acceptance of $\mathrm{CP}$ donations is that all the patients who recovered from COVID-19 were invited by the TRC to make $\mathrm{CP}$ donations, meaning that the $\mathrm{CP}$ donors were from the many different cities across the country, leading to a large study sample, which increased the power of the study.

\section{CONCLUSION}

In the present study, we analyzed the 8-month temporal dynamics of the SARS-CoV-2 antibody response in $\mathrm{CP}$ donors and observed the presence of SARS-CoV-2 antibodies up to the 244th day following the onset of PCR positivity. The highest mean IgG antibody ratios were in the AB, Rh (-) and $\mathrm{AB}$ Rh $(+)$ blood groups, while the lowest ratios were seen in the $\mathrm{O}, \mathrm{Rh}(+)$ and $\mathrm{O} R \mathrm{Rh}(+)$ blood groups. Besides as BMI increased, so did the mean IgG antibody ratios; and a higher mean IgG antibody ratio was noted in the adults aged 35-60 years. In the light of these results, the BMI and age range of individuals with a certain blood group may be preferred for this treatment mode in terms of the effectiveness of CP for the treatment of COVID-19 patients.

We believe that the underlying dynamics of the antibody response and its relationship with the $\mathrm{ABO} \&$ Rh blood groups, age, and BMI will be an important area of future research. In addition, the clinical implications of such dynamics, such as the duration of antibody persistence after PCR positivity and the absolute level of the antibodies that are sufficiently protective to prevent SARSCoV-2 reinfection, will also be important areas for future research.

\section{REFERENCES}

1. World Health Organization. Coronavirus disease (COVID19) pandemic. Switzerland; 2021. Avaliable from: https:// www.who.int/emergencies/diseases/novel-coronavirus2019 (Accessed: August 19, 2021).

2. T.C. Sağlık Bakanlığı. Türkiye COVID-19 Hasta Tablosu. Turkey; 2021. Avaliable from: https://covid19.saglik. gov.tr/ (In Turkish. Accessed: August 19, 2021).

3. Cao WC, Liu W, Zhang PH, Zhang $\mathrm{F}$, Richardus JH. Disappearance of antibodies to SARS-associated coronavirus after recovery. NEnglJMed. 2007;357:1 162-3. [CrossRef]

4. Payne DC, Iblan I, Rha B, et al. Persistence of antibodies against Middle East Respiratory Syndrome Coronavirus. Emerg Infect Dis. 2016;22:1824-6. [CrossRef]

5. Zhao J, Yuan $\mathrm{Q}$, Wang $\mathrm{H}$, et al. Antibody responses to SARS-CoV-2 in patients with novel coronavirus disease 2019. Clin Infect Dis. 2020;71:2027-34. [CrossRef]

6. O Murchu E, Byrne P, Walsh KA, et al. Immune response following infection with SARS-CoV-2 and other coronaviruses: A rapid review. Rev Med Virol. 2021;31:e2162. [CrossRef]

7. The Food and Drug Administration. Investigational COVID-19 Convalescent Plasma Emergency INDs. USA; 2020. Avaliable from: https://notifylibrary.org/sites/ default/files/Investigational\%20COVID - 19\%20 Convalescent $\% 20$ Plasma\%20-\%20Emergency $\% 20$ INDs\%20_\%20FDA.pdf (Accessed: May 31, 2021).

8. European Commission Directorate-General For Health And Food Safety. Brussels; 2021. Avaliable from: https:// ec.europa.eu/health/sites/health/files/blood_tissues_ organs/docs/guidance_plasma_covid19_en.pdf (Accessed: May 31, 2021).

9. T.C. Sağlık Bakanlığı. COVID-19 İmmün (Konvalesan) Plazma Tedarik ve Klinik Kullanim Rehberi. Turkey; 2021. Avaliable from: https://shgmkanhizmetleridb.saglik.gov. tr/Eklenti/39167/0/covid-19-immun-plazma-rehberi-v5. pdf (In Turkish. Accessed: May 31, 2021).

10. Rahim F, Amin S, Bahadur S, Noor M, Mahmood A, Gul H. ABO / Rh-D Blood types and susceptibility to Corona Virus Disease-19 in Peshawar, Pakistan. Pak J Med Sci. 2021;37:4-8. [CrossRef]

11. Yılmaz $M$, Karaca $A$, Sözmen $N N$, et al. Association between COVID-19 and ABO Blood Groups: An analysis on convalescent plasma donors in Turkey. Med Bull Haseki. 2021;59:7-14. [CrossRef]

12. Ward $\mathrm{H}$, Atchison $\mathrm{C}$, Whitaker $M$, et al. Antibody prevalence for SARS-CoV-2 following the peak of the pandemic in England: REACT2 study in 100,000 adults. medRxiv. 2020:2020.08.12.20173690. [CrossRef]

13. Marra A, Generali D, Zagami P, et al. Seroconversion in patients with cancer and oncology health care workers infected by SARS-CoV-2. Ann Oncol. 2021;32:113-9. [CrossRef] 
14. Belda F, Lopez-Martinez $M$, Torres N, Cherenzia R, Crowley M. Available COVID-19 serial seroconversion panel for validation of SARS-CoV-2 antibody assays. Diagn Microbiol Infect Dis. 2021;100:115340. [CrossRef]

15. Seow J, Graham C, Merrick B, et al. Longitudinal observation and decline of neutralizing antibody responses in the three months following SARS-CoV-2 infection in humans. Nat Microbiol. 2020;5:1598-607. [CrossRef]

16. Qiu X, Xiang Y, Sun J, et al. Dynamic changes of throat swabs RNA and serum antibodies for SARS-CoV-2 and their diagnostic performances in patients with COVID19. Emerg Microbes Infect. 2020;9:1974-83. [CrossRef]

17. lyer AS, Jones FK, Nodoushani A, et al. Persistence and decay of human antibody responses to the receptor binding domain of SARS-CoV-2 spike protein in COVID19 patients. Sci Immunol. 2020;5(52).

18. Rodda LB, Netland J, Shehata L, et al. Functional SARSCoV-2-Specific immune memory persists after mild COVID-19. Cell. 2021;184:169-83. [CrossRef]

19. Choe PG, Kang CK, Suh HJ, et al. Waning antibody responses in asymptomatic and symptomatic SARSCoV-2 infection. Emerg Infect Dis. 2021;27:327-9. [CrossRef]

20. Flinck H, Rauhio A, Luukinen B, et al. Comparison of 2 fully automated tests detecting antibodies against nucleocapsid N and spike S1/S2 proteins in COVID-19. Diagn Microbiol Infect Dis. 2021;99:115197. [CrossRef]

21. Canas JJ, Starr MC, Hooks J, et al. Longitudinal SARSCoV-2 seroconversion and functional heterogeneity in a pediatric dialysis unit. Kidney Int. 2021;99:484-6. [CrossRef]

22. Lumley SF, O’Donnell D, Stoesser NE, et al. Antibody status and incidence of SARS-CoV-2 infection in health care workers. N Engl J Med. 2021;384:533-40. [CrossRef]

23. Wendel S, Fontao-Wendel R, Fachini R, et al. A longitudinal study of convalescent plasma (CCP) donors and correlation of $A B O$ group, initial neutralizing antibodies ( $\mathrm{nAb}$ ), and body mass index (BMI) with $\mathrm{nAb}$ and anti-nucleocapsid (NP) SARS-CoV-2 antibody kinetics: Proposals for better quality of CCP collections. Transfusion. 2021;61:144760. [CrossRef]

24. Zhang X, Lu S, Li H, et al. Viral and antibody kinetics of COVID-19 patients with different disease severities in acute and convalescent phases: a 6-month follow-up study. Virol Sin. 2020;35:820-9. [CrossRef]
25. Gaebler C, Wang Z, Lorenzi JCC, et al. Evolution of antibody immunity to SARS-CoV-2. Nature. 2021;591(7851):639-44. [CrossRef]

26. Mai HK, Trieu NB, Long TH, et al. Long-term humoral immune response in persons with asymptomatic or mild SARS-CoV-2 infection, Vietnam. Emerg Infect Dis. 2021;27:663-6. [CrossRef]

27. Dan JM, Mateus J, Kato Y, et al. Immunological memory to SARS-CoV-2 assessed for up to 8 months after infection. 2021;371:eabf4063. [CrossRef]

28. Glück V, Grobecker S, Tydykov L, et al. SARS-CoV-2directed antibodies persist for more than six months in a cohort with mild to moderate COVID-19. Infection. 2021;49:739-46. [CrossRef]

29. Karbiener $M$, Farcet $M R$, Ilk R, et al. Longitudinal analysis of SARS-CoV-2 antibodies in 8000 U.S. first-time convalescent plasma donations. Transfusion. 2021;61:1141-7. [CrossRef]

30. Maine GN, Lao KM, Krishnan SM, et al. Longitudinal characterization of the IgM and IgG humoral response in symptomatic COVID-19 patients using the Abbott Architect. J Clin Virol. 2020;133:104663. [CrossRef]

31. Bloch EM, Patel EU, Marshall C, et al. ABO blood group and SARS-CoV-2 antibody response in a convalescent donor population. Vox Sang. 2021;116:766-73. [CrossRef]

32. Yang HS, Costa V, Racine-Brzostek SE, et al. Association of age with SARS-CoV-2 antibody response. JAMA Netw Open. 2021;4:e214302. [CrossRef]

33. Klein SL, Pekosz A, Park HS, et al. Sex, age, and hospitalization drive antibody responses in a COVID-19 convalescent plasma donor population. J Clin Invest. 2020;130:6141-50. [CrossRef]

34. Lumley SF, Wei J, O'Donnell D, et al. The duration, dynamics and determinants of SARS-CoV-2 antibody responses in individual healthcare workers. Clin Infect Dis. 2021;73:e699-709. [CrossRef]

35. World Health Organization. Health Topics, Body Mass Index. Available from: https://www.euro.who.int/en/ h e a l t h - topics / d is e a s e - prevention / nutrition/a-healthy-lifestyle/body-mass-index-bmi (Accessed: May 31, 2021).

36. Wendel S, Kutner JM, Machado R, et al. Screening for SARS-CoV-2 antibodies in convalescent plasma in Brazil: Preliminary lessons from a voluntary convalescent donor program. Transfusion. 2020;60:2938-51. [CrossRef] 